\title{
Rapid accumulation of an interleukin 17 homolog transcript in Crassostrea gigas hemocytes following bacterial exposure
}

\author{
Steven Roberts ${ }^{\mathrm{a}}$, Yannick Gueguen ${ }^{\mathrm{b}}$, Julien de Lorgeril $^{\mathrm{b}}$ and Frederick Goetz ${ }^{\mathrm{c}, ~ *}$
}

\footnotetext{
a School of Aquatic and Fisheries Science, University of Washington-Seattle, Box 355020, 1122 NE Boat Street, Seattle, WA 98105, USA

${ }^{\mathrm{b}}$ Ifremer-CNRS-Université de Montpellier II, UMR 5119 Ecosystèmes Lagunaires-Place E. Bataillon, CC80, F34095 Montpellier cedex 5, France

${ }^{\mathrm{c}}$ Great Lakes WATER Institute, University of Wisconsin-Milwaukee, 600 E. Greenfield Avenue, Milwaukee, WI 53204, USA
}

*: Corresponding author : Frederick Goetz, email address : rick@uwm.edu

\begin{abstract}
:
Interleukin-17 (IL-17) gene models have been found in the sequenced genomes of Strongylocentrotus purpuratus and Caenorhabditis elegans. However, there have been no published reports on the empirical cloning and characterization of any interleukin CDNAs in invertebrates. From a Pacific oyster (Crassostrea gigas) hemocyte cDNA library, two clones were obtained that encoded a protein similar to vertebrate IL-17s. The putative oyster IL-17 homolog (CgIL-17) was $27 \%$ identical to rainbow trout IL-17D, 21\% to human IL-17D and 24\% to an IL-17D-like gene model obtained from the annotation of the sea urchin genome. IL-17s from the oyster, sea urchin, trout and human, contained conserved cysteine residues found in all forms of IL-17 in mammals. Injection of bacteria into C. gigas oysters produced a large and rapid elevation in CglL-17 transcript abundance in hemocytes, suggesting that this is a very early response gene to pathogens that may be responsible for the stimulation of other immune genes in the oyster.
\end{abstract}

Keywords: Interleukin; Pacific oyster; Hemocytes; Invertebrate cytokines; Crassostrea gigas; Invertebrate innate immunity 


\section{Introduction}

Cytokines comprise a large number of regulatory molecules many of which function within the vertebrate immune system, including interleukins, interferons and chemokines. Invertebrates produce a large number of molecules involved in the innate immune response to pathogens including, antimicrobial peptides, proteases and protease inhibitors, lysozymes and lectins. While there are comparative immunohistochemical and experimental data to suggest that cytokines are also present in invertebrates [1], several large-scale genomic analyses of sequenced genomes (S. purpuratus; D. melanogaster; C. intestinalis) have not observed chemokines [2] or helical cytokines [3]. However, using a "QT helical cytokine fold recognition approach," a putative helical cytokine was recently characterized from the Drosophila genome [4]. The recent sequencing of the sea urchin (Strongylocentrotus purpuratus) genome has provided a further look into the evolution and complexity of invertebrate immune systems [5]. However, many of the cytokine and chemokine groups found in the vertebrate immune system were not detected in the sea urchin genome [6]. The exception to this was the presence of tumor necrosis factor (TNF) homologs [7] and a number of potential interleukin 17 (IL-17) homologs [6].

In mammals, six IL-17 forms (A-F) and five receptors have been identified [8,9]. While the functions of many of the IL-17 forms are still being characterized, one function of IL-17A in mammals is the release of a number of other cytokines involved in neutrophil and macrophage recruitment. IL-17A is produced by a specific subset of activated T cells and, as such, is responsible for crosstalk between the adaptive and innate immune system [9]. In mammals, IL17A has been implicated in many inflammatory and autoimmune conditions including arthritis, Crohn's disease, psoriasis, asthma, and cystic fibrosis [8]. While IL-17s have actions in the 
mammalian immune system that are similar to other cytokines, they are not structurally related to other interleukin or cytokine families.

To our knowledge, there have been no published reports of the empirical cloning of an invertebrate interleukin. In an expressed sequence tag (EST) analysis of plated hemocytes from the Pacific oyster, Crassostrea gigas, we observed two clones containing sequences that exhibited greatest amino acid identity to vertebrate IL-17s. Based on their function in mammals, we characterized the expression of the gigas $I L-17$ following bacterial stimulation.

\section{Methods}

\subsection{Isolation and sequencing}

Two separate complimentary DNA (cDNA) clones of the putative oyster IL-17 homolog $(C g I L-17)$ were obtained from ESTs derived from the random sequencing of cDNA libraries constructed in Zap Express (Stratagene). The libraries were made from mRNA obtained from $C$. gigas hemocytes that were isolated from the hemolymph of Pacific oysters and plated for $24 \mathrm{~h}$ on poly-lysine coated plates at $12^{\circ} \mathrm{C}$. The two cDNAs were then fully sequenced using vector primers in both directions. All chromatogram sequences of the two clones were trimmed for quality using phred (http://www.phrap.org/phrap.docs/phred.html), vector screened using cross match (http://www.phrap.org/phrap.docs/phrap.html) and analyzed locally using blastx against the NCBI nonredundant (nr) protein database and blastn against the NCBI nucleotide (nt) database. Amino acid sequence comparisons were made with ClustalW [10], using the BLOSUM series matrix and the following parameters; open gap penalty - 10, gap extension penalty -0.05 , delay divergent sequences $-40 \%$. Gene models from the sea urchin were obtained from the Baylor College of Medicine annotation site: 
http://annotation.hgsc.bcm.tmc.edu/Urchin/pubLogin.html. Signal peptide prediction was performed with the SignalP software (www.cbs.dtu.dk/services/SignalP).

\subsection{Animals, tissue collection and immune challenge}

Adult $C$. gigas (3 years old; $12 \mathrm{~cm}$ ), were purchased from a local oyster farm in Palavas (France) and kept in sea water at $15^{\circ} \mathrm{C}$. Oysters were stimulated by immersion (with $5 \times 10^{8}$ bacteria/litre) or injection $\left(5 \times 10^{6}\right.$ bacteria/animal). For the immersion challenge, bacteria were added in the sea water tank with the oysters at the start of the infection. The microorganisms used for the challenge were heat-killed bacterial strains of Micrococcus luteus, Vibrio splendidus and Vibrio anguillarum. The bacterial strains were grown separately overnight in saline peptone water ( $1.5 \%$ peptone, $0.25 \mathrm{M} \mathrm{NaCl}, \mathrm{pH} 7.2)$ at $25^{\circ} \mathrm{C}$ for Vibrio strains and in Luria-Bertani medium for M. luteus $\left(30^{\circ} \mathrm{C}\right)$. Bacteria were collected by centrifugation $(10000 \mathrm{~g}, 5 \mathrm{~min})$ and suspended in fresh growth medium. Bacteria concentration was calculated from the optical density at $550 \mathrm{~nm}$ and the concentration verified by plating the bacteria.

Hemolymph was collected from challenged and unchallenged oysters at different times (24 and $48 \mathrm{~h}$ ) from the pericardial cavity through the adductor muscle with an equal volume of anti-aggregate Modified Alsever Solution (27 mM sodium citrate, $336 \mathrm{mM} \mathrm{NaCl}, 115 \mathrm{mM}$ glucose, 9 mM EDTA, pH 7.0) and immediately centrifuged at $700 \mathrm{~g}$ for $10 \mathrm{~min}\left(4^{\circ} \mathrm{C}\right)$ to separate the blood cells from plasma. After hemolymph collection, oyster tissues were harvested by dissection. Tissue samples (gills, digestive gland, heart, labial palps, adductor muscle and mantle; 100 to $300 \mathrm{mg}$ ) were then collected, washed in sterile sea water, cut into small pieces and incubated overnight at $4^{\circ} \mathrm{C}$ in Trizol reagent $(1 \mathrm{ml} / 100 \mathrm{mg}$ of tissue). Total RNA was purified using Trizol reagent according to the manufacturer's instruction (Invitrogen). 


\subsection{Real time PCR analyses}

Total RNA, pooled from tissue samples, was analysed from non-stimulated and stimulated oysters for each time of collection using a real time polymerase chain reaction (rtPCR). For $C g I L-17$, the forward and reverse primers were IL-17F (5'-ACTGAGGCTCG ATGCAAGTG-3') and IL-17R (5'-AGCCTTCTTGCTTCATGTGG-3'). The gene encoding elongation factor (ef, GenBank AB122066) was used as an internal control with forward and reverse primers EF-F (5'-GAGCGTGAACGTGGTATCAC-3') and EF-R (5'-ACAGCA CAGTCAGCCTGTGA-3'), respectively.

Total RNA was treated with DNAse (Invitrogen) to eliminate contaminating genomic DNA. The DNAse was removed by phenol chloroform extraction. Following heat denaturation $\left(70^{\circ} \mathrm{C}\right.$ for $\left.5 \mathrm{~min}\right)$, reverse transcription was performed using $1 \mu \mathrm{g}$ of total RNA prepared with 50 $\mathrm{ng} / \mu \mathrm{l}$ oligo-(dT) $)_{12-18}$ in a $20 \mu \mathrm{l}$ reaction volume containing $1 \mathrm{mM}$ dNTPs, 1 unit/ $\mu \mathrm{l}$ of RNAseOUT and 200 units/ $\mu 1$ MMLV reverse transcriptase in reverse transcriptase buffer according to the manufacturer's instructions (Invitrogen). rtPCR amplifications were performed in the LightCycler 480 (Roche). Briefly, the following components were mixed to the indicated endconcentration: $5 \mathrm{mM} \mathrm{MgCl} 2,0.5 \mu \mathrm{M}$ of each primer, $2.5 \mu \mathrm{l}$ of reaction mix (LightCycler®) 480 SYBR Green I Master) in a final volume of $5 \mu$. Reverse transcribed RNA $(1 \mu \mathrm{l})$ was added as the PCR template to the LightCycler master mix and the following run protocol used: initial denaturation at $95^{\circ} \mathrm{C}$ for $10 \mathrm{~min} ; 95^{\circ} \mathrm{C}$ for $10 \mathrm{~s} ; 55^{\circ} \mathrm{C}$ for $20 \mathrm{~s} ; 72^{\circ} \mathrm{C}$ for $25 \mathrm{~s}$ with a single fluorescence measurement; melting curve program $\left(73-95^{\circ} \mathrm{C}\right.$ with a heating rate of $0.1^{\circ} \mathrm{C} / \mathrm{s}$ and a continuous fluorescence measurement) and finally a cooling step to $30^{\circ} \mathrm{C}$. Each PCR experiment was performed in triplicate. For further expression level analysis, the crossing points $(\mathrm{CP})$ were determined for each transcript using the LightCycler software. Specificity of the rtPCR product 
was analyzed on an agarose gel and by melting curve analysis. The copy ratio of each analyzed cDNA was determined as the average of two replicates. The relative expression ratio of $C g I L-17$ was calculated based on the CP deviation of each rtPCR product of RNA extracted from stimulated oyster versus the appropriate control sample, and expressed in comparison to the reference gene (elongation factor; ef). The relative expression ratio of $C g$ - $I L 17$ was calculated based on the delta-delta method for comparing relative expression results defined as: ratio $=2^{-[\Delta \mathrm{CPsample}-\text { mean of all } \Delta \mathrm{CP}]}=2^{-\Delta \Delta \mathrm{CP}}[11]$.

\section{Results}

\subsection{Sequence analysis of Crassostrea gigas IL-17 (CgIL-17)}

Both $C g I L-17$ clones, obtained from the hemocyte library, had open reading frames and were identical with one another except that one was longer on the 5 ' end. When both cDNAs were assembled using CAP3 (Contig Assembly Program [12]) they produced a combined cDNA of 824 bp encoding a protein of 200 amino acids (Accession \#EF190193). This protein had several potential methionine start sites in the 5' end, but based on the alignment with other IL17s (Figure 1) and particularly with a sea urchin IL-17, the first methionine appeared more likely to be the start site.

When the $C g \mathrm{IL}-17$ protein was compared to other sequences in Genbank, it was most similar to IL-17D forms. The $C g \mathrm{IL}-17$ was $27 \%$ identical to rainbow trout IL-17D and $21 \%$ to human IL-17D (Figure 1). There is an IL-17 homolog (BAD22762) in the NBCI database for Ciona intestinalis, but it is much smaller in length compared to vertebrate IL-17s, and is only $16 \%$ identical to the $C g \mathrm{IL}-17$. There is also an IL-17 form (NP_505700) for Caenorhabditis

elegans that is similar in size but is only $17 \%$ identical to $C g \mathrm{IL}-17$. Further, when the $C$. elegans 
and the $C$. intestinalis sequences are aligned to other Genbank sequences, they appear to be more similar to IL-17C (Table 1). There are at least 22 sea urchin IL-17 gene models that have some identity with vertebrate IL-17s ([6]; Table 1). For comparison to the oyster IL-17 sequence, the sea urchin gene model (SPU_030196) that was most similar to the highest blast hit (rainbow trout IL-17D) for $C g I L-17$, was used. This particular sea urchin protein was $24 \%$ identical to CgIL-17 (Figure 1).

As indicated in Figure 1 (circled residues), there are several positions in the IL-17 protein that appear to be nearly identical across the different IL-17 forms (A-F) in mammals (e.g. [13]) and are primarily located in the $\mathrm{C}$ terminus. However, these are not always conserved residues in the oyster or the sea urchin IL-17. In contrast, there are six conserved cysteine residues present in all of the IL-17Ds aligned (Figure 1). In mammalians, 5 of these 6 cysteines (Figure 1: cysteine \#s 1, 3, 4-6) are conserved across all IL-17 forms. In addition, there are several other amino acids that are present in human IL-17D, trout IL-17D, oyster and urchin IL-17s but are not typically conserved across the different IL-17 forms in mammals [13] (asterisks; Figure 1).

\subsection{Expression of $\mathrm{CgIL-17}$}

Real-time polymerase chain reaction (rtPCR) analysis was completed to determine whether acute changes in CgIL-17 RNA abundance could be detected in different tissues and in hemocytes sampled at several times following bacterial stimulation. $C g I L-17$ was expressed constitutively in several tissues but was highest in the gills (Figure 2). When stimulated by bacteria through immersion, there was no clear-cut increase in $C g I L-17$ abundance in hemocytes (Figure 3). However, injection of bacteria stimulated a very strong increase in CgIL-17 mRNA 
abundance in oyster hemocytes by $6 \mathrm{~h}$ (Figures 4). This increase slowly declined through 24 and 48 hours (Figure 4).

\section{Discussion}

To our knowledge, this is the first published report of an empirically cloned invertebrate interleukin cDNA. Genome analysis has revealed the presence of putative interleukin 17 proteins in several invertebrates including the sea urchin [6] and Caenorhabditis elegans (NP_505700), and an IL-17 homolog (BAD22762) for Ciona intestinalis is present in the NBCI database. In fact, there are at least 22 gene models in the sea urchin genome that have some identity to vertebrate IL-17s. In mammals, 6 forms of IL-17s, labeled A-F, have been described [13]. When the sea urchin gene models are blasted individually against the NCBI database, there are forms that are similar to IL-17D, IL-17B, and IL-17E (Table 1). Since the oyster $C g \mathrm{IL}-17$ was most similar to trout IL-17D, the sea urchin gene model closest to trout IL-17D (SPU_030196) was used in the sequence alignment presented here. The $C$. intestinalis and $C$. elegans IL-17s appear to be more similar to IL-17C (Table 1), and showed lower similarity to $C g \mathrm{IL}-17$ as compared to the sea urchin sequence.

So far, the large numbers of cytokines present in vertebrates do not appear in the invertebrate genomes that have been sequenced. A major exception to this is IL-17. However, IL-17s are actually not structurally similar to other interleukin superfamily members [14]. Thus, it is possible that while most cytokine families may have evolved solely within the vertebrate lineage, the family represented by IL-17s may have evolved prior to the divergence of vertebrates and invertebrates. This might explain their presence in the sea urchin genome when other interleukins appear to be absent. Experimental data concerning the effects and receptor 
binding of vertebrate cytokines in invertebrate systems, suggest that interleukins are present in invertebrates (e.g. [1]). However, it has also been suggested that functional convergence may have occurred between invertebrates and vertebrates such that non homologous molecules might be performing similar functions (e.g., pathogen recognition) [15]. Further, the reason that vertebrate molecules may seem to be present in invertebrates could be a result of the convergence of key epitopes on structurally different molecules, making them appear to have similarities in binding to receptors or antibodies as a result of these key epitopes.

Specific features, that are present in all IL-17s, are 5 conserved cysteine residues that are also conserved in the oyster and urchin IL-17s. Of these cysteines, 4 (cysteines 1, 3, 5 \& 6: Figure 1) are believed to be involved in forming a cysteine knot [16] that is similar to a motif exhibited in growth factors such as BMP and TGF- $\beta$ s [13]. There were several amino acid residues found to be identical in the human, trout, oyster and urchin IL-17s when aligned. Interestingly, besides the cysteines, most of these amino acids are not conserved between different mammalian IL-17 forms (A-F), suggesting that IL-17Ds may have their own unifying structure spanning vertebrates and invertebrates.

The $C g I L-17$ sequence came from a cDNA library constructed from RNA obtained from oyster hemocytes that had been plated and incubated overnight. In the present study, $C g I L-17$ was expressed to some extent in all tissues examined, though levels in the heart and adductor muscle were comparatively low. In mammals, there are large differences in the tissue expression of IL-17s. Some IL-17s are only expressed in a small subset of cells [8], whereas IL-17D is expressed in a large number of tissues including skeletal muscle, brain, adipose tissue, heart, lung and pancreas [17]. If $C g I L-17$ is restricted to hemocytes in oysters, it is possible that 
expression in various tissues is related to the presence of hemocytes, and may explain why $C g I L$ 17 expression was very high, for example, in the gills.

Based on the function of IL-17s in mammals, we were interested to determine if abundance of $C g I L-17$ transcripts was regulated by bacterial exposure in oyster hemocytes. Oysters exposed in the water to bacteria, did not appear to have a readily discernable elevation in CgIL-17 transcript levels in hemocytes. However, hemocytes from oysters injected with bacteria had a very large and rapid increase in CgIL-17 transcript levels that was highly elevated by $6 \mathrm{~h}$ (Figure 4). In fact, the transcription of this gene probably occurs even prior to 6 hours indicating that it is a very early response gene. The quick response to bacteria could be the reason why CgIL-17 transcript levels were not elevated when oysters were exposed to bacteria in the water, since in that case samples may not have been taken early enough. In mammals, IL-17 is produced by activated memory T cells [18]. Even though it is produced by cells of the adaptive immune system, it appears that IL-17 plays a major role in innate immunity since it can stimulate a number of proinflammatory mediators including prostaglandin endoperoxide synthase 2 , inducible nitric oxide syntase, IL-6, chemokines involved in neutrophil recruitment such as IL-8, CXCL1, and MIP2, matrix metalloproteinases and acute phase proteins ([8] for review). It also appears that IL-17 synergizes with other proinflammatory mediators such as TNF [19]. Several genes coding for proteins involved with inflammation or innate immunity have been isolated from oysters. Specifically, a TGF- $\beta$ /activin homologue was isolated from oysters that was elevated in hemocytes following exposure to bacteria [20]. Similarly, an inhibitor of tissue metalloproteinase was isolated during a differential display analysis of bacterial-challenged oyster hemocytes [21]. Transcripts of this inhibitor were rapidly (6-9 hours) upregulated following shell damage or following bacterial injection [21]. Chitinase-like genes have also been 
isolated from oysters that are strongly regulated by bacterial LPS following in vivo injection and during primary cell culture of hemocytes [22]. While no direct connection has been made in oysters between IL-17 and other genes, it is possible that with the fast response of $\mathrm{CgIL-17}$ to bacteria, IL-17 may be regulating the expression of some of these other genes upon pathogen exposure.

\section{Acknowledgements}

This research was supported in part by the Cooperative State Research Education and Extension Service, US Department of Agriculture, under Agreement No. 2003-38500-13505 (SR).

\section{References Cited}

[1] Raftos D, Nair S. Tunicate cytokine-like molecules and their involvement in host defense responses. Prog Mol Subcell Biol 2004;34:165-82.

[2] DeVries ME, Kelvin AA, Xu L, Ran L, Robinson J, Kelvin DJ. Defining the origins and evolution of the chemokine/chemokine receptor system. J Immunol 2006;176 (1):401-15.

[3] Huising MO, Kruiswijk CP, Flik G. Phylogeny and evolution of class-I helical cytokines. J Endocrinol 2006;189 (1):1-25.

[4] Malagoli D, Conklin D, Sacchi S, Mandrioli M, Ottaviani E. A putative helical cytokine functioning in innate immune signalling in Drosophila melanogaster. Biochim Biophys Acta 2007;1770 (6):974-8.

[5] Sodergren E, Weinstock GM, Davidson EH, Cameron RA, Gibbs RA, Angerer RC, Angerer LM, Arnone MI, Burgess DR, Burke RD, Coffman JA, Dean M, Elphick MR, Ettensohn CA, Foltz KR, Hamdoun A, Hynes RO, Klein WH, Marzluff W, McClay DR, Morris RL, Mushegian A, Rast JP, Smith LC, Thorndyke MC, Vacquier VD, Wessel GM, Wray G, Zhang L, Elsik CG, Ermolaeva O, Hlavina W, Hofmann G, Kitts P, Landrum MJ, Mackey AJ, Maglott D, Panopoulou G, Poustka AJ, Pruitt K, Sapojnikov V, Song X, Souvorov A, Solovyev V, Wei Z, Whittaker CA, Worley K, Durbin KJ, Shen Y, Fedrigo O, Garfield D, Haygood R, Primus A, Satija R, Severson T, Gonzalez-Garay ML, Jackson AR, Milosavljevic A, Tong M, Killian CE, Livingston BT, Wilt FH, Adams N, Belle R, Carbonneau S, Cheung R, Cormier P, Cosson B, Croce J, Fernandez-Guerra A, Geneviere AM, Goel M, Kelkar H, Morales J, Mulner-Lorillon O, Robertson AJ, Goldstone JV, Cole B, Epel D, Gold B, Hahn ME, Howard-Ashby M, Scally M, Stegeman JJ, Allgood EL, Cool J, Judkins KM, McCafferty SS, Musante AM, Obar RA, 
Rawson AP, Rossetti BJ, Gibbons IR, Hoffman MP, Leone A, Istrail S, Materna SC, Samanta MP, Stolc V, Tongprasit W, Tu Q, Bergeron KF, Brandhorst BP, Whittle J, Berney K, Bottjer DJ, Calestani C, Peterson K, Chow E, Yuan QA, Elhaik E, Graur D, Reese JT, Bosdet I, Heesun S, Marra MA, Schein J, Anderson MK, Brockton V, Buckley KM, Cohen AH, Fugmann SD, Hibino T, Loza-Coll M, Majeske AJ, Messier C, Nair SV, Pancer Z, Terwilliger DP, Agca C, Arboleda E, Chen N, Churcher AM, Hallbook F, Humphrey GW, Idris MM, Kiyama T, Liang S, Mellott D, Mu X, Murray G, Olinski RP, Raible F, Rowe M, Taylor JS, Tessmar-Raible K, Wang D, Wilson KH, Yaguchi S, Gaasterland T, Galindo BE, Gunaratne HJ, Juliano C, Kinukawa M, Moy GW, Neill AT, Nomura M, Raisch M, Reade A, Roux MM, Song JL, Su YH, Townley IK, Voronina E, Wong JL, Amore G, Branno M, Brown ER, Cavalieri V, Duboc V, Duloquin L, Flytzanis C, Gache C, Lapraz F, Lepage T, Locascio A, Martinez P, Matassi G, Matranga V, Range R, Rizzo F, Rottinger E, Beane W, Bradham C, Byrum C, Glenn T, Hussain S, Manning G, Miranda E, Thomason R, Walton K, Wikramanayke A, Wu SY, Xu R, Brown CT, Chen L, Gray RF, Lee PY, Nam J, Oliveri P, Smith J, Muzny D, Bell S, Chacko J, Cree A, Curry S, Davis C, Dinh H, Dugan-Rocha S, Fowler J, Gill R, Hamilton C, Hernandez J, Hines S, Hume J, Jackson L, Jolivet A, Kovar C, Lee S, Lewis L, Miner G, Morgan M, Nazareth LV, Okwuonu G, Parker D, Pu LL, Thorn R, Wright R. The genome of the sea urchin Strongylocentrotus purpuratus. Science 2006;314 (5801):941-52.

[6] Hibino T, Loza-Coll M, Messier C, Majeske AJ, Cohen AH, Terwilliger DP, Buckley KM, Brockton V, Nair SV, Berney K, Fugmann SD, Anderson MK, Pancer Z, Cameron RA, Smith LC, Rast JP. The immune gene repertoire encoded in the purple sea urchin genome. Dev Biol 2006;300 (1):349-65.

[7] Robertson AJ, Croce J, Carbonneau S, Voronina E, Miranda E, McClay DR, Coffman JA. The genomic underpinnings of apoptosis in Strongylocentrotus purpuratus. Dev Biol 2006;300 (1):321-34.

[8] Gaffen SL, Kramer JM, Yu JJ, Shen F. The IL-17 cytokine family. Vitam Horm 2006;74:255-82.

[9] Kramer JM, Gaffen SL. Interleukin-17: a new paradigm in inflammation, autoimmunity, and therapy. J Periodontol 2007;78 (6):1083-93.

[10] Thompson JD, Higgins DG, Gibson TJ. CLUSTAL W: improving the sensitivity of progressive multiple sequence alignment through sequence weighting, position-specific gap penalties and weight matrix choice. Nucleic Acids Res 1994;22 (22):4673-80.

[11] Livak KJ, Schmittgen TD. Analysis of relative gene expression data using real-time quantitative PCR and the 2(-Delta Delta C(T)) Method. Methods 2001;25 (4):402-8.

[12] Huang X, Madan A. CAP3: A DNA sequence assembly program. Genome Res 1999;9 (9):868-77.

[13] Moseley TA, Haudenschild DR, Rose L, Reddi AH. Interleukin-17 family and IL-17 receptors. Cytokine Growth Factor Rev 2003;14 (2):155-74.

[14] Yu JJ, Gaffen SL. Interleukin-17: A novel inflammatory cyokine that bridges innate and adaptive immunity. Frontiers in Bioscience 2008;13:170-7.

[15] Beschin A, Bilej M, Magez S, Lucas R, De Baetselier P. Functional convergence of invertebrate and vertebrate cytokine-like molecules based on a similar lectin-like activity. Prog Mol Subcell Biol 2004;34:145-63.

[16] Hymowitz SG, Filvaroff EH, Yin JP, Lee J, Cai L, Risser P, Maruoka M, Mao W, Foster J, Kelley RF, Pan G, Gurney AL, de Vos AM, Starovasnik MA. IL-17s adopt a cystine 
knot fold: structure and activity of a novel cytokine, IL-17F, and implications for receptor binding. Embo J 2001;20 (19):5332-41.

[17] Starnes T, Broxmeyer HE, Robertson MJ, Hromas R. Cutting edge: IL-17D, a novel member of the IL-17 family, stimulates cytokine production and inhibits hemopoiesis. $\mathrm{J}$ Immunol 2002;169 (2):642-6.

[18] Yao Z, Painter SL, Fanslow WC, Ulrich D, Macduff BM, Spriggs MK, Armitage RJ. Human IL-17: a novel cytokine derived from T cells. J Immunol 1995;155 (12):5483-6.

[19] Ruddy MJ, Shen F, Smith JB, Sharma A, Gaffen SL. Interleukin-17 regulates expression of the CXC chemokine LIX/CXCL5 in osteoblasts: implications for inflammation and neutrophil recruitment. J Leukoc Biol 2004;76 (1):135-44.

[20] Lelong C, Badariotti F, Le Quere H, Rodet F, Dubos MP, Favrel P. Cg-TGF-beta, a TGFbeta/activin homologue in the Pacific Oyster Crassostrea gigas, is involved in immunity against Gram-negative microbial infection. Dev Comp Immunol 2007;31 (1):30-8.

[21] Montagnani C, Le Roux F, Berthe F, Escoubas JM. Cg-TIMP, an inducible tissue inhibitor of metalloproteinase from the Pacific oyster Crassostrea gigas with a potential role in wound healing and defense mechanisms(1). FEBS Lett 2001;500 (1-2):64-70.

[22] Badariotti F, Lelong C, Dubos MP, Favrel P. Characterization of chitinase-like proteins (Cg-Clp1 and Cg-Clp2) involved in immune defence of the mollusc Crassostrea gigas. Febs J 2007;274 (14):3646-54. 


\section{Figure Legends}

Figure 1 : Alignment of IL-17Ds from human (NP_612141), rainbow trout (CAE45584), oyster (EF190193) and sea urchin (SPU_030196) performed using ClustalW. Conserved residues are highlighted in grey. Residues conserved across all IL-17 forms (A-F) in mammals are circled within the human sequence. Residues that appear to be conserved across animal D-like IL-17s, but are not conserved between IL-17 forms in mammals, are indicated by an asterisk below the residue. Conserved cysteines are indicated by numbers (1-6) below the cysteines. Putative signal peptides are underlined and alternative methionine in the oyster sequence is indicated by a triangle. Amino acid numbers refer to the primary translation products.

Figure 2: Expression of $C g I L-17 \mathrm{mRNA}$ analyzed by real time PCR in tissues from unchallenged oysters. Each value represents the relative expression of $\mathrm{CgIL-17}$ in the hemocytes (He), gills (G), mantles (M), adductor muscles (AM), labial palps (LP), digestive glands (DG) and hearts $(\mathrm{H})$ from one pool of five animals. Bars represent the relative $C g I L-17$ transcript levels normalized to ef transcript levels. Each value is the average of triplicates $\pm \mathrm{SD}$.

Figure 3: Hemocyte expression of $C g I L-17 \mathrm{mRNA}$ at 24 and $48 \mathrm{~h}$ analyzed by real time PCR following bacterial stimulation by immersion and injection. $C g I L-17$ mRNA expression was measured in hemocytes from non-stimulated oysters $(\mathrm{N})$ and following bacterial challenge by immersion (Im) and injection (Inj) at 24 and $48 \mathrm{~h}$ post-infection. The results of two independent experiments (black and grey) performed on a pool of ten oysters are shown. Bars represent the 
relative $C g I L-17$ transcript levels normalized to ef transcript levels, as described in Methods. The $\Delta \Delta \mathrm{CP}$ values for each experimental condition were obtained by subtraction of the mean of all $\Delta \mathrm{CPs}$ (relative expression of the mean of conditions $=1$ ).

Figure 4: Hemocyte expression of $C g I L-17 \mathrm{mRNA}$ at 6,24 and $48 \mathrm{~h}$ analyzed by real time PCR following bacterial stimulation by injection. The results of two independent experiments (black and grey) performed on a pool of ten oysters are shown. Bars represent the relative $C g I L-17$ transcript levels at 6,24 and 48 h normalized to ef transcript levels, as described in Methods. The $\Delta \Delta \mathrm{CP}$ values for each experimental condition were obtained by subtraction of the mean of all $\Delta \mathrm{CPs}$ (relative expression of the mean of conditions $=1$ ). 


\section{Figure 1}

Trout IL17D

Human IL17D

Oyster IL17

Urchin IL17

Trout IL17D

Human IL17D

Oyster IL17

Urchin IL17

Trout IL17D

Human IL17D

Oyster IL17

Urchin IL17

Trout IL17D

Human IL17D

Oyster IL17

Urchin IL17

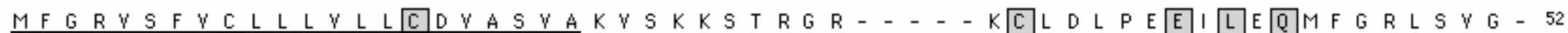

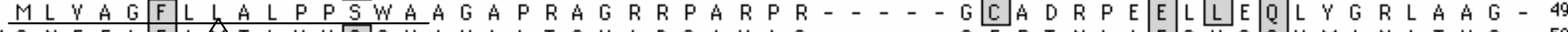


MA Q D D L F F T T F A I A A V S C C S L M T S R V I S S P T I D R A N H G N V T C R E P N T T E L T S M L A L A V A R N 58

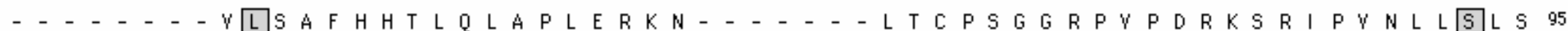

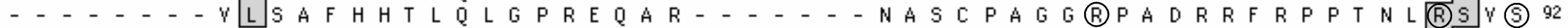

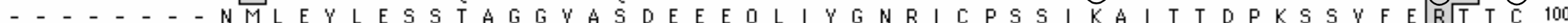

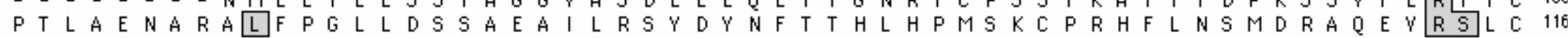

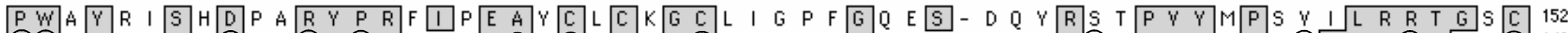

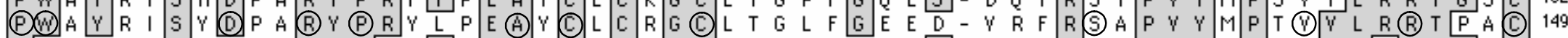

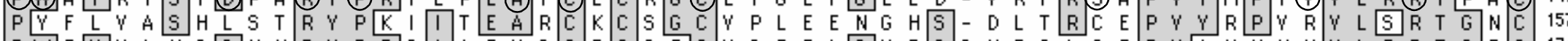



123
* $\quad$

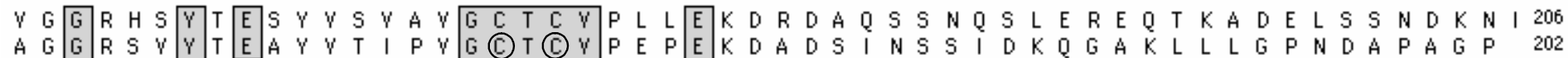

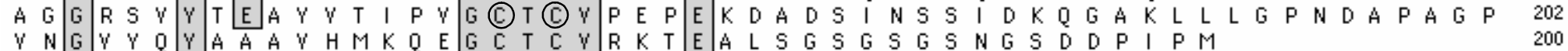
I NG V Q R Y E E E F E P Y P MACD V C E R F A S R M S I N

204 
Figure 2

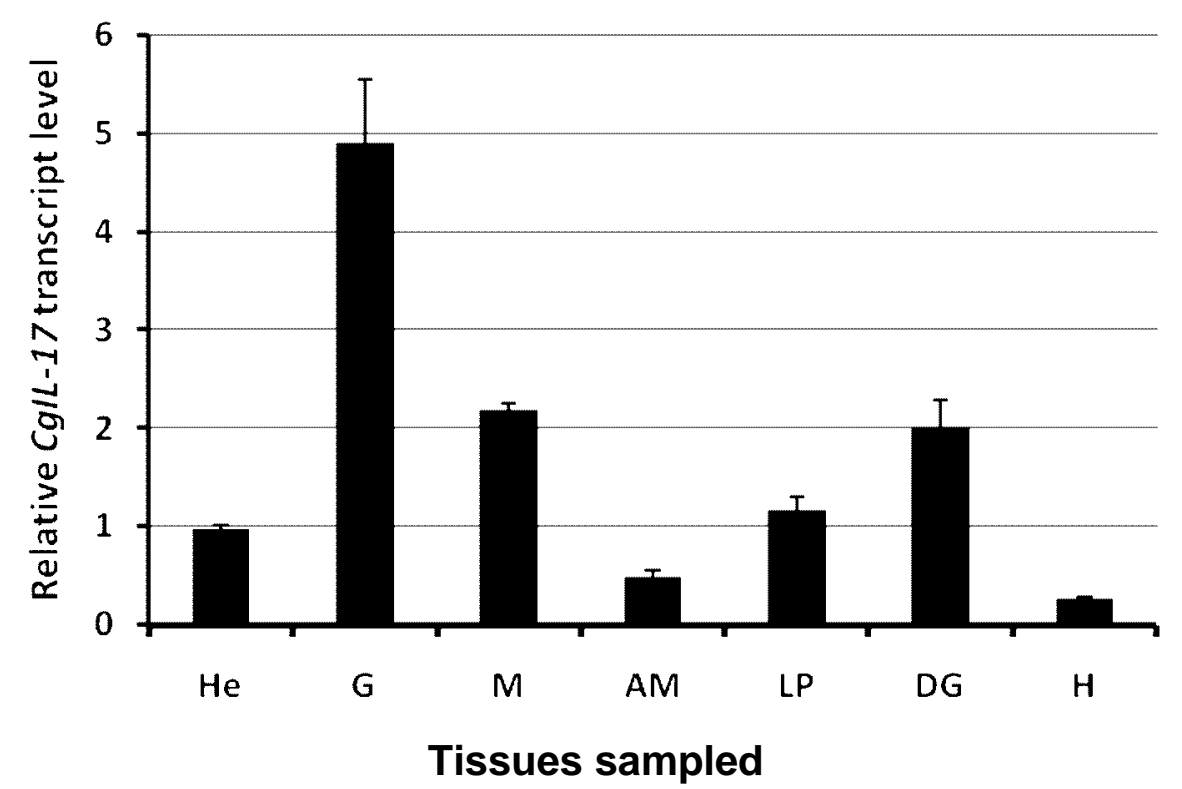


Figure 3

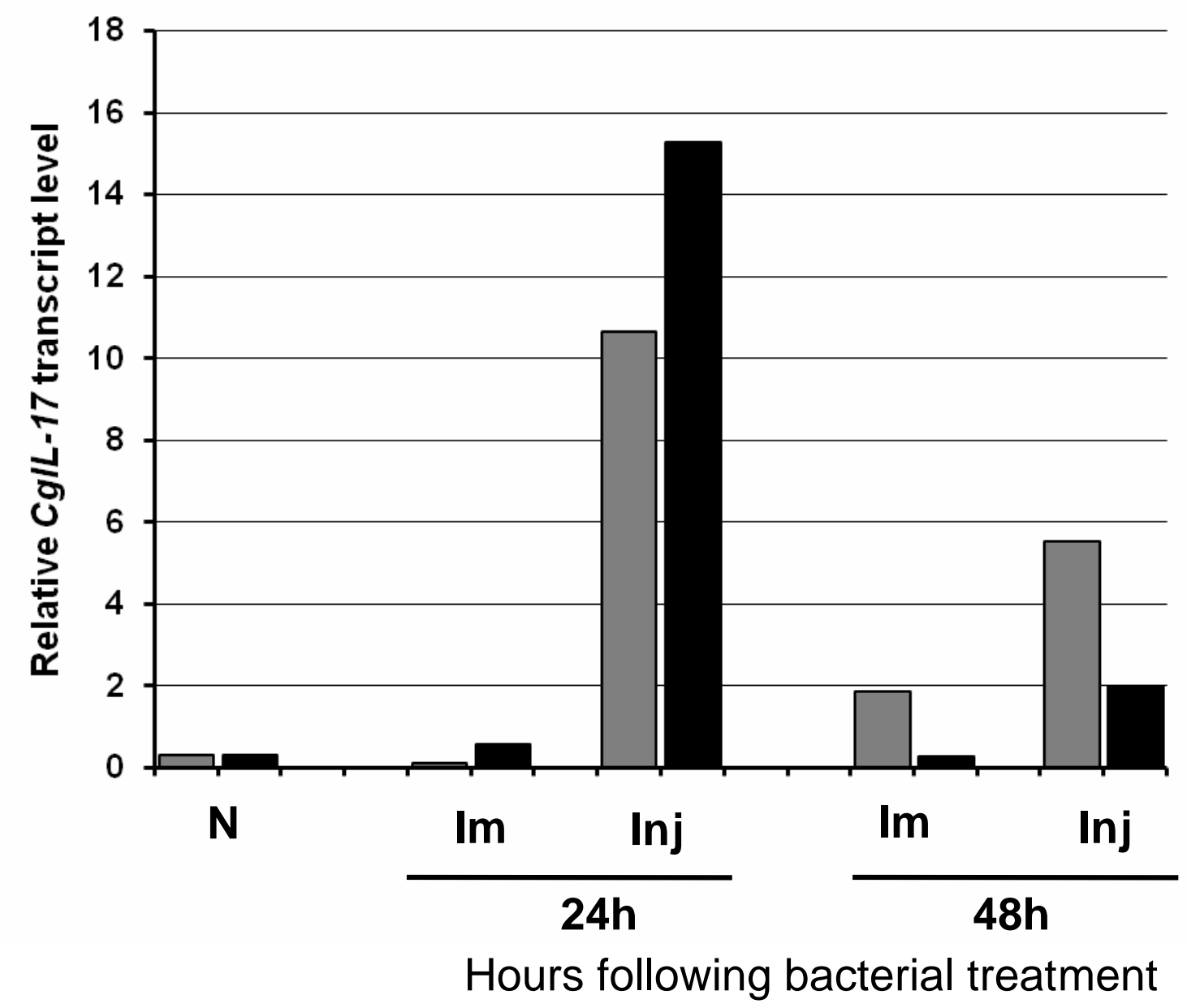


Figure 4

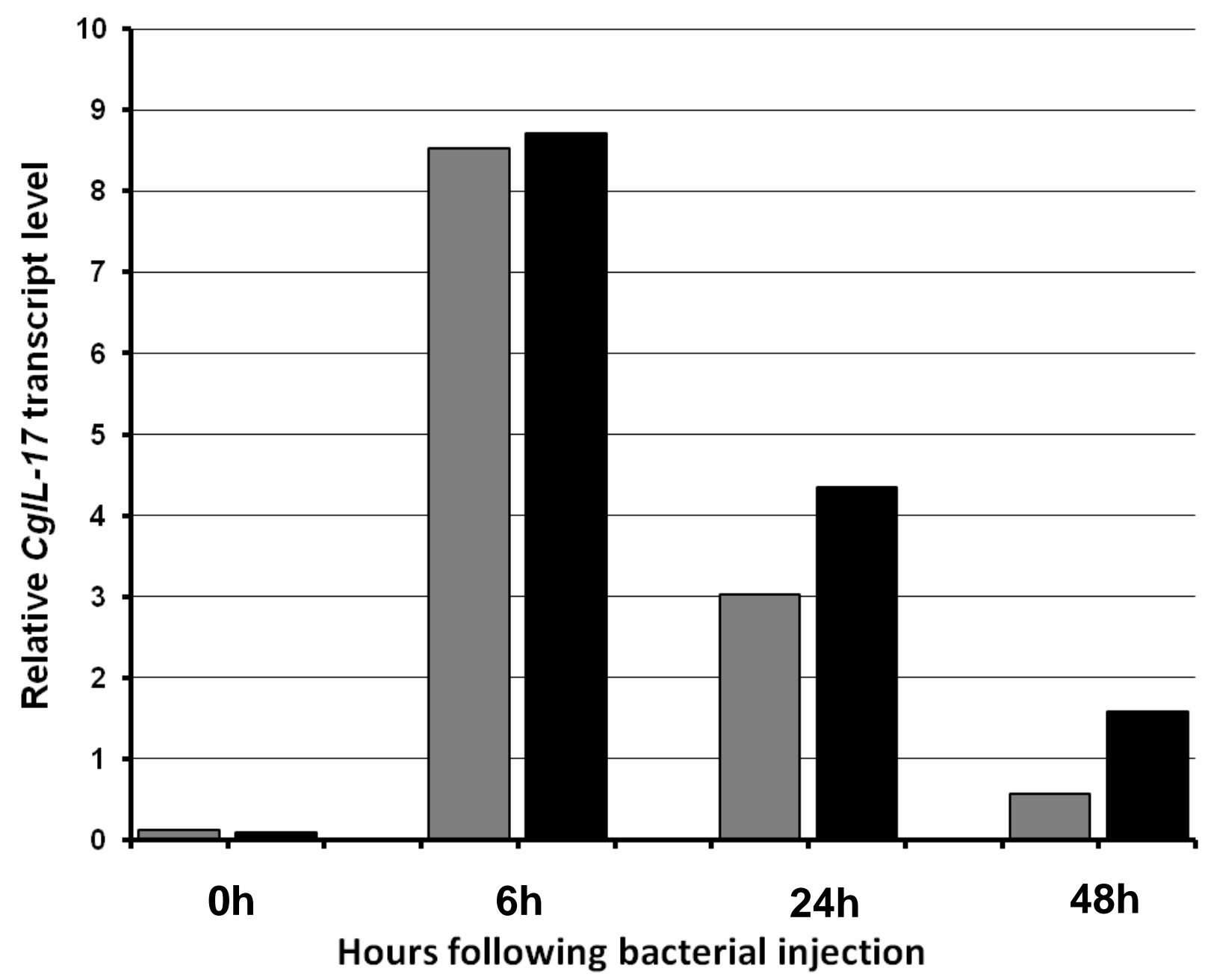


Table 1: Blastx comparisons of IL17s from S. purpuratus, C. intestinalis, and C. elegans with NCBI nr database

\begin{tabular}{|c|c|c|c|c|}
\hline Sequence ID & $\begin{array}{c}\text { Sequence } \\
\text { Length }\end{array}$ & $\begin{array}{l}\text { Most Similar } \\
\text { Genbank Hit }\end{array}$ & Hit Description Including [Species] & E-Value \\
\hline \multicolumn{5}{|l|}{ S. purpuratus $^{a}-$} \\
\hline [SPU_005983] & 191 & XP_001375129 & PREDICTED: similar to IL17D [Monodelphis domestica] & $1 \mathrm{E}-11$ \\
\hline [SPU_012844] & 536 & XP_001375129 & PREDICTED: similar to IL17D [Monodelphis domestica] & $1 \mathrm{E}-07$ \\
\hline [SPU_012845] & 181 & XP_001375129 & PREDICTED: similar to IL17D [Monodelphis domestica] & $2 \mathrm{E}-12$ \\
\hline [SPU_019349] & 184 & XP_001375129 & PREDICTED: similar to IL17D [Monodelphis domestica] & $2 \mathrm{E}-09$ \\
\hline [SPU_019350] & 537 & XP_001375129 & PREDICTED: similar to IL17D [Monodelphis domestica] & $1 \mathrm{E}-09$ \\
\hline [SPU_019351] & 188 & XP_001375129 & PREDICTED: similar to IL17D [Monodelphis domestica] & 3E-09 \\
\hline [SPU_022838] & 379 & EDM14616 & interleukin 17B, isoform CRA_b [Rattus norvegicus] & $8 \mathrm{E}-08$ \\
\hline [SPU_027904] & 260 & AAK59816 & interleukin 17E precursor [Mús musculus] & $2 \mathrm{E}-05$ \\
\hline [SPU-030184] & 186 & NP 001006699 & Interleukin 17B [Xenopus tropicalis] & $1 \mathrm{E}-02$ \\
\hline [SPU_030185] & 190 & NP_001006699 & interleukin 17B [Xenopus tropicalis] & $8 \mathrm{E}-01$ \\
\hline [SPU_030186] & 191 & NP_001006699 & interleukin 17B [Xenopus tropicalis] & $2 \mathrm{E}-03$ \\
\hline [SPU_030188] & 209 & EDM14205 & similar to IL25 ${ }^{\mathrm{b}}$ (predicted) [Rattus norvegicus] & $1 \mathrm{E}-08$ \\
\hline [SPU_030190] & 188 & EDM14205 & similar to IL25 (predicted) [Rattus norvegicus] & $1 \mathrm{E}-04$ \\
\hline [SPU_030191] & 215 & AF458059_1 & IL25 [Homo sapiens] & 3E-04 \\
\hline [SPU_030192] & 254 & EDM14205 & similar to IL25 (predicted) [Rattus norvegicus] & $1 \mathrm{E}-04$ \\
\hline [SPU_030193] & 209 & EDM14205 & similar to IL25 (predicted) [Rattus norvegicus] & $2 \mathrm{E}-07$ \\
\hline [SPU_030196] & 204 & CAE45584 & interleukin 17 isoform D [Oncorhynchus mykiss] & $1 \mathrm{E}-07$ \\
\hline [SPU_030197] & 300 & XP_871741 & PREDICTED: similar to interleukin 27 [Bos taurus] & $1 \mathrm{E}-01$ \\
\hline [SPU_030198] & 344 & EDM14205 & similar to IL25 (predicted) [Rattus norvegicus] & 3E-09 \\
\hline [SPU_030199] & 236 & XP_001375129 & PREDICTED: similar to IL17D [Monodelphis domestica] & $7 \mathrm{E}-12$ \\
\hline [SPU_030200] & 181 & XP_001375129 & PREDICTED: similar to IL17D [Monodelphis domestica] & $1 E-09$ \\
\hline [SPU_030204] & 215 & AAK59816 & interleukin 17E precursor [Mus musculus] & $6 \mathrm{E}-04$ \\
\hline \multicolumn{5}{|l|}{ C. elégans - } \\
\hline $\begin{array}{l}\text { NP_505700 } \\
\text { C. intestinalis - }\end{array}$ & 89 & XP_874908 & PREDICTED: similar to cytokine $\mathrm{C} \times 2^{\mathrm{C}}$ precusor [Bos taurus] & $1 \mathrm{E}-05$ \\
\hline BAD22762 & 186 & XP_001376801 & PREDICTED: similar to IL17C [Monodelphis domestica] & $2 \mathrm{E}-07$ \\
\hline
\end{tabular}

${ }^{a}$ Baylor College of Medicine annotation site: http://annotation.hgsc.bcm.tmc.edu/Urchin/pubLogin.html

b IL25 and IL17E are the same

${ }^{c}$ cytokine CX2 and IL-17C are the same 